\title{
Improving the freight transport of a developing economy: a case of Boankra inland port
}

\author{
Richmond Kwesi Ansah ${ }^{1 *} \mathbb{D}$, Kwabena Obiri-Yeboah² and Grace Akipelu²
}

\author{
* Correspondence: \\ richmondgansah@gmail.com \\ ${ }^{1}$ Hong Kong Baptist University, \\ Kowloon Tong, Hong Kong \\ Full list of author information is \\ available at the end of the article
}

\begin{abstract}
Purpose: Shippers and Freight Forwarding Agents spend much time clearing their cargo from the Ghanaian ports. As a result, the cost of doing business in Ghana through the Tema and Takoradi ports is high. This research investigates the potential impact the establishment of an inland port will have on a reduction in congestion at the Tema and Takoradi ports and on the efficiency of the freight transport system.
\end{abstract}

Methodology/approach: This study used questionnaires to gather data through an experience survey conducted at the Ghana Sea Ports and Boankra inland port.

Findings: The study found out that for the inland Port to work effectively, there should be a connection from the Boankra inland port to the Takoradi and Tema Sea Ports as well as the container depots of the neighboring landlocked Sub-Saharan African Countries.. The study discovered that the implementation of the Boankra inland port will result in the decongestion and efficiency of Ghanaian seaports. Factors such as the increase in skills and experience of personnel; the use of management information systems; formulation of programmes and policies in decongesting the two main Ghanaian seaports; enhanced road network; adaptation of new technologies in the cargo handling process; and reduced bureaucracy in clearing processes at the ports are arbitrating factors through which the establishment of the Boankra inland port may have an impact on the seaports and the Freight transport industry at large. It was found that the challenges which may impede the improvement of freight transport in Ghana are inefficiencies and distortions in the trading system; unnecessary bureaucratic clearing processes; weak regulatory framework; Poor quality control; inadequate staff; political interference, and lack of capital. It was found that for the Boankra Inland Port to be efficient, the officials and stakeholders must be trained; the various institutions in the transport chain must be empowered; corruption among port officials must be managed; there must be minimal political interference in the port operations; there must be more investment into the freight transport system; and there must be trade regulations to govern the freight transport system.

Originality: This novel study differentiates itself from existing studies on Port System by focusing on inland ports in Africa and their influence on the efficiency and decongestion of seaports.

Keywords: Regionalization, Boankra inland port, Congestion, Port efficiency 


\section{Introduction}

Goods are rarely consumed where they are produced, making transport services essential at all stages of the supply chain. Improving freight transport can be a real point of competitive differentiation because international trade is a commonplace and increasing market share in emerging markets is highly desirable (Bartlett and Ghoshal 2002).

Transport is an essential component of every economy. According to Kondo (2014), transport accounts for as much as $30 \%$ of the total cost of freight and logistics operations so when a port (i.e. Seaport, Inland, or Airport) cannot meet its capacity, it creates congestion. However, the capital requirement for the construction of new ports and other infrastructure to improve freight transportation is huge. In an attempt to keep pace with the rapidly developing freight transport market, governments are devoting resources to expand transport infrastructure and to build new transport systems. It is, therefore, essential for the development of port infrastructure to be based on a tested knowledge to justify the huge investment outlay involved.

Several literatures have been written over the past 25 years to address inland port development as a means of improving freight transportation, but only one study has been conducted on an inland port in Africa within the 25 years' period (Witte et al. 2019). It indicates that the concept of inland ports in Africa is understudied despite the revolving confusion on the subject. This study which is novel in West Africa is a feasibility study conducted on the Ongoing Boankra Inland Port project being built in the Middle belt region of Ghana. The Boankra Inland Port will be linked to the Takoradi Port and the Tema Port. The Takoradi Port is in the western part of Ghana and it is Ghana's first commercial port, opened in 1928 to serve the needs of the mining industry and to handle imports of consumer goods. The Takoradi Port is connected to its hinterland which makes it the preferred and ideal gateway to the central and northern part of Ghana and the Sahelian countries of Burkina Faso, Niger, and Mali (Ghana Ports and Harbours Authority 2014). The Port has six (6) berths with draughts between $8.4 \mathrm{~m}$ and $10 \mathrm{~m}$ in addition to dedicated manganese, bauxite, and oil berths (See Fig. 1). In 2019, the port handled 10,384,067 t of freight and 1628 vessel calls. Leading exports include manganese, bauxite, forest products and bulk and bagged cocoa beans, mining equipment; while leading imports include clinker, wheat, petroleum products, and containerized cargo (Logistics Capacity Assessment 2019a). The Boankra Inland Port is aimed at facilitating the movement of freight to and from the Takoradi Port to the hinterlands.

The Port of Tema is the largest in Ghana, situated on the eastern coast of the country. It stretches over 3.9 million square metres of land area (See Fig. 2). The port receives an average of over 1650 vessel calls per year. These comprise container vessels, general cargo vessels, tankers, Ro-Ro, and cruise vessels among many others. $85 \%$ of Ghana's trade is done through the ports with shipping routes and vessel calls to and from all continents through both direct and transshipment services. Set within the industrial city of Tema and $30 \mathrm{~km}$ from the capital city of Ghana, the port's environs serve as a logistic point for activities of Inland Clearance Depots (ICDs), warehouses, transport and haulage companies, freight forwarders, factories, and related service centres. The Takoradi Port and Tema Ports both serve their hinterland, including the landlocked countries Burkina Faso, Niger, and Mali. Therefore, the construction of the Boankra Inland port is to facilitate the connection the ports have with their hinterlands (Logistics Capacity Assessment 2019b). 


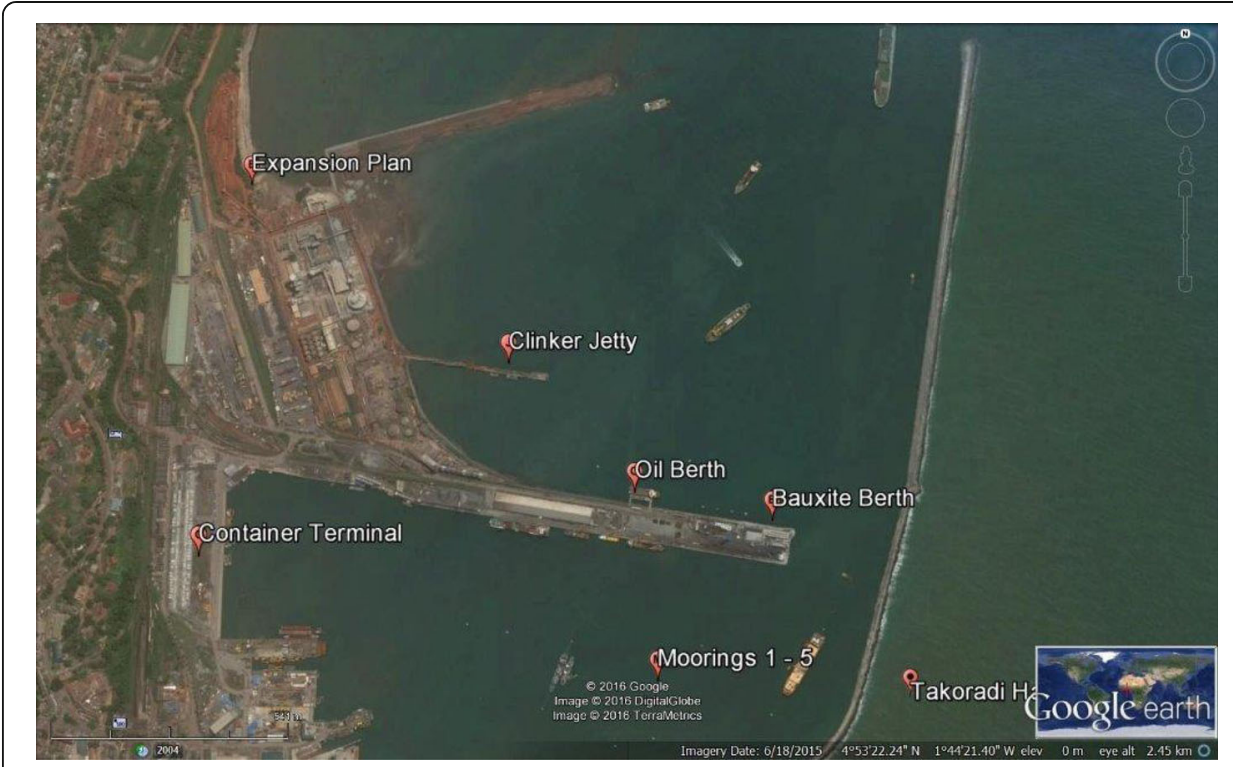

\section{Source: Logistics Capacity Assessment (2019) - Courtesy of Google Earth}

Fig. 1 Satellite View of Takoradi Port

The Boankra inland port, though it is being built in Ghana, is envisaged to serve three landlocked West African Countries which include Burkina Faso, Niger, and Mali. Hence, a study of this project is essential to provide scientific knowledge on the inland ports in west Africa. Currently, freights transiting to these landlocked countries that will be served by the Inland Port mostly pass through the Takoradi and Tema Ports in Ghana (See Fig. 3 for the Geographical coverage of the Boankra inland port).

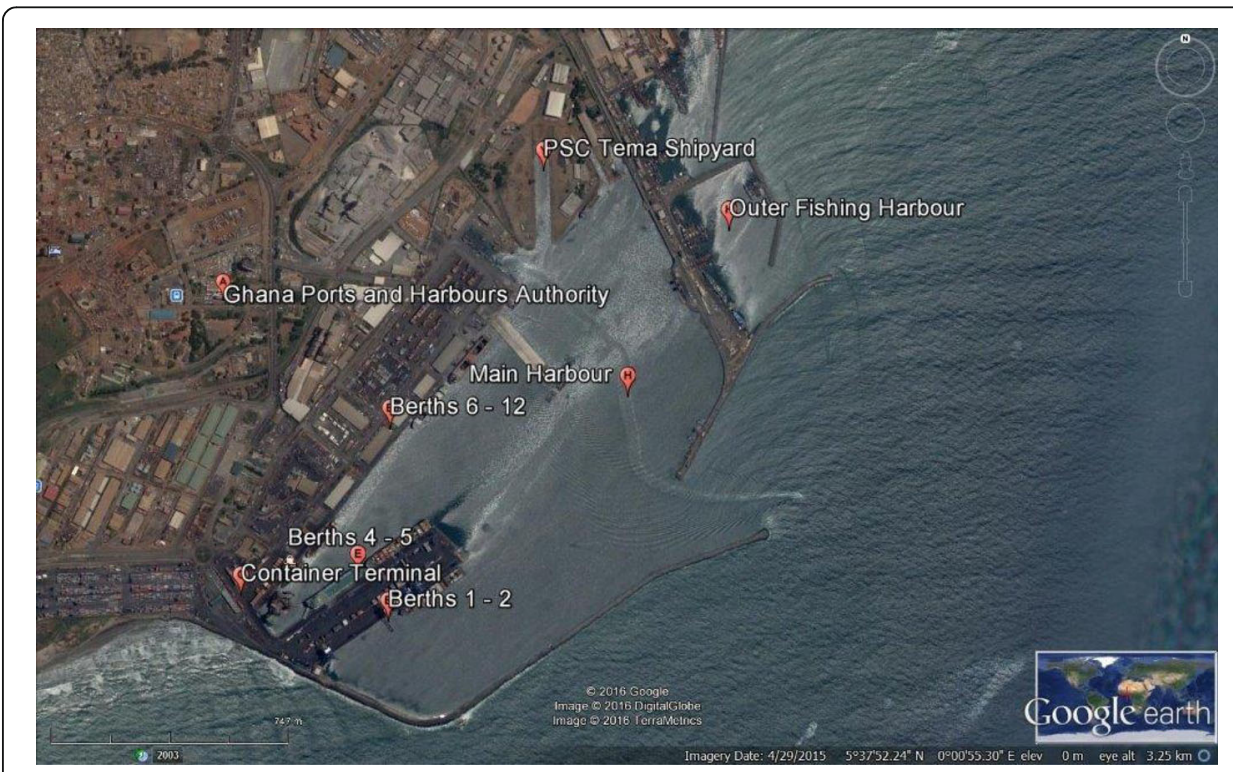

Source: Logistics Capacity Assessment (2019) - Courtesy of Google Earth

Fig. 2 Satellite View of Tema Port 
The conceptualization of Inland ports is very difficult because much of the existing literature on the concept focuses on Inland Ports as a component of logistics and transport, and largely neglects the leading role of Inland ports in the regional freight transport system (Witte et al. 2019). Rodrigue et al. (2010) stated that "the role and function of inland ports have been the object of some confusion since there is no specific consensus, even concerning the definition itself." This shows that the subject of inland ports requires more study. This research aims to assess how the public-private partnership building of the Boankra Inland Port can be used to improve the freight transport system in Sub-Saharan Africa.

Notteboom and Rodrigue's (2005) addition of port regionalization to the model developed by Bird (1980) started the discussion on port regionalization which was supported by Rimmer and Comtois (2009) and Monios and Wilmsmeier (2012). It was argued by Rimmer and Comtois that port regionalization means decentralization but Notteboom and Rodrigue (2005) argued that "the transition towards the port regionalization phase is a gradual and market-driven process, imposed on ports, that mirrors the increased focus of market players on logistics integration." (p301). This also raised a discussion on whether regionalization is an imposition on ports.

Freight transportation is increasing exponentially in Ghana owing to economic growth and growing international trade within the country which has some ripple effect on neighboring countries like Togo, Burkina Faso, Benin, Liberia, La Cote Devoir, Mali, and Niger. According to the Ghana Ports and Harbours Authority (GPHA), total cargo traffic volumes at the Port of Tema rose by 1,269,288 $\mathrm{t}$ in 2016 representing an increase of $10.5 \%$ as compared to the previous year. There was also a very significant increase in local exports by $25.3 \%$ in 2016 (Obeng 2010). The trade activities in Ghana largely affect neighboring landlocked countries as shown in Fig. 3. Yet, the citizenry and public officials complain about inefficiencies in the Ghanaian seaports. It is announced that the Boankra Inland Port is being constructed to correct the inefficiencies and to promote efficiency and effectiveness in the Ghanaian freight transport system. It is therefore essential to study the causes of the inefficiencies in the Ghanaian freight transport

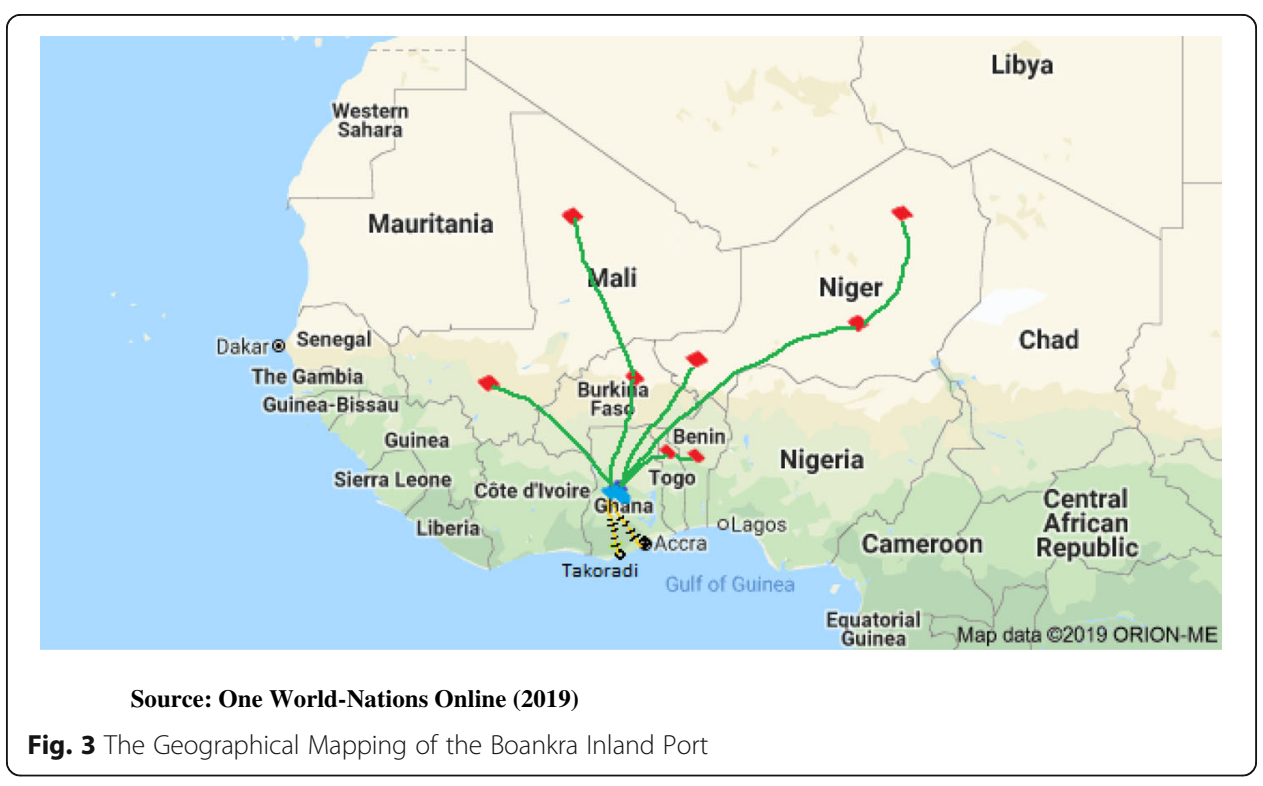


system and how the private-public sector partnership project on the Boankra Inland Port can be developed to enhance the general freight transport system.

The objectives of the study are threefold: 1) to assess the efficiency and the potential impact of the Boankra Inland Port on the sea freight transport in Ghana, 2) to assess the current challenges in the freight transport system in Ghana and 3) to assess the potential impact of the Boankra inland Port on the efficiency of the seaports in Ghana. This study is aimed at providing information from the West African context to contribute to the ongoing scholarly debate on inland port development and port regionalization.

\section{Literature review}

Inland port development

Inland ports have been described and classified in so many forms. In existing pieces of literature, inland port is termed as dry port, inland terminal, inland facilities, and inland hub, inland logistics Centre and freight villages. Generally, all these terms are connected to inland intermodal workstations and diverse roles that allow inland ports to provide a diversity of logistics facilities. As stated by some prior writers, three major physical characteristics that describe inland ports: intermodal stations - railway or inland waterways; linking with the port station (stations) by road and railway transportation and/or inland watercourse all over a big volume corridor; and Classes of related logistic operations that arrange shipment conveyance.

Inland Ports provide warehousing functions in the freight transport system. Beresford and Dubey (1990) described inland ports as inland clearance yards. The term dry port is the most acknowledged term for describing inland ports and it is defined to be inland customs warehouse (Wilmsmeier et al. 2011). Harrison et al. (2004) reported that inland ports supply the area they are situated via intermodal stations, which are essential components of the inland port. Roso (2008) suggested the term land port and defined the term as an inland intermodal station which is linked straight to port(s) with extraordinary volume transportation way(s), where clienteles can leave or pick up their regular entities as if directly to a port.

Inland Ports facilitate the movement and clearance of goods. According to ESCAP (2010), inland port offers assistance for managing and provision of stowage of containers and huge freights that go in or come out the inland port by any transport mode such as road, rail, air, and inland waterways. Customs and other related services, like examination of freights for exportation and importation, whenever it is probable is carried out in the inland port. The term inland port is usually applied to show that an assumed inland port reached a particular standard concerning offering services, such as customs processes and the existence of 3PL logistics workers and other facilities.

Inland ports are essential for controlling port congestions. Slack (1999) described inland ports as the answer to ports overcrowding and as well talked about four logistic roles of freight stations: freight movement amid two conveyance modes; freight gathering to be transported; warehousing of freight pending gathering; supply and freight logistic management. He reported that facilities such as container repairs, customs check, and some other important facilities are required to be part of inland ports. Inland ports vary in different geographical environs due to the differences in location on the transportation system, shapes, facilities, and roles (Rodrigue et al. 2010; Veenstra et al. 2012; Van den Berg and De Langen 2015; Monios 2011).

Inland ports are classified based on the functions they perform: transportation purpose factor (road, road-rail, road-inland watercourse, road-rail-inland watercourse 
station), and factor of logistics purposes (e.g. solely customs processes, simple stowage activities, stowage activities of a broad scope of facilities, manufacturing operation, even trade, and wholesale operations).

\section{Role of actors in the inland port development}

The provision of public infrastructure is traditionally seen as the responsibility of the Government. The Government of Ghana (GoG) is seen as a key actor in the Ghanaian freight transport system. However, the government facing serious challenges with infrastructure development and public service delivery which in turn constrains the growth of the economy (Bank of Ghana 2015). With limited budgets, Ghana's huge deficit in infrastructure cannot be met by the public sector alone. According to the Africa infrastructure diagnostic report (AICD) in 2010, Ghana needs approximately $\$ 1.5$ billion per annum over the next decade to address its transport infrastructure deficit (Patalinghug et al. 2015). With Ghana's attainment of lower-middle-income country status, sources of concessional funding from donors and development agencies will keep drying up. It was therefore important for the government to find alternative sources of funding for new investments and enhancement of existing transport infrastructure to develop the economy. This led to the proposal of the Public-Private Partnership development of the Boankra inland port. Therefore, some private institutions have also become major actors in the Ghanaian Freight Transport system as investors. The identity of these private institutions are not disclosed yet, but there are seven private investors in the Boankra Inland Port Project (BusinessGhana 2018).

Projections from Ghana Shippers Authority (GSA) and Ghana Ports and Harbours Authority (GPHA), which are the Government Agency directing the affairs of the freight transport system, show that there is potential for growth in the maritime freight transport sector in Ghana. The agencies mentioned that the key players in the Ghanaian freight transport industry are: freight forwarders, shipping agents, Burkina /Mali chamber of commerce, Ghana importers association, cargo owners, seaports and harbor Authorities, Haulage transport association, private terminal operators, Ghana Railway Development Authority, Ministry of Transport and Ministry of Trade and Industry.

\section{Overview of the Boankra inland port}

The Boankra inland port is a project initiated by the Ghana Shippers Authority (GSA) and the Ghana Ports and Harbours Authority (GPHA) in partnership with the private sector. The inland port is being built near Kumasi which is the Largest Commercial city in Ghana situated in the Middle Belt of Ghana. The inland port will primarily link the two major seaports in Ghana: Tema seaport and Takoradi Port and the landlocked countries of Burkina Faso, Mali, and Niger (Ghana Shippers Authority 2019).

The Boankra Inland project is estimated to cost approximately $\$ 1.5$ to $\$ 2.0$ billion, of which $\$ 300$ to $\$ 500$ million of the investment is contributed by the private sector and the rest is funded by the State (Global Infrastructure Facility 2018). The Boankra inland port is named after the town it is being built. It is located in the Mid-Region of Ghana within the Ashanti Region.

The project comprises of two parts: the construction of the Inland Port and the construction and rehabilitation of the Eastern Railway Line from Tema seaports (Accra) and Takoradi Sea Port (Takoradi) (Shown in Fig. 3). The project is located in Kumasi. The 
eastern corridor railway lines are being constructed to connect the inland port from Boankra to the Takoradi and Tema Seaports in Ghana (See Fig. 1). The Boankra inland ports will also serve the Kali Bamako and Soterko-Bamako inland containers in Mali; the Niamey and Dosso inland containers in Niger and TRCB (Terminal Routier à Conteneur de Boborinter) and SETO (Société d'Exploitation du Terminal de Ouagadougou) inland depots in Ougadougou, Burkina Faso (Bollore Ports 2019) (see map in Fig. 3).

Currently, the Boankra Inland Port has been partially developed with an administration block, access roads, and utility connections. Other plans for the further development of the Inland Port will include an Inland Container Depot (“ICD"), port administration, shippers and freight forwarders offices, warehouses, and commercial buildings. Development of primary infrastructure namely roads, drains, water supply, sewage, electricity and telecommunications, Inland Clearance Depot, Custom Bonded, and Unbonded Estates, Vehicle and Car Parking Lots, Commercial Estates, Light Industrial Estates, Social/Civic Estates, and other port facilities; and the completion of the Administrative Complex (Ministry of Finance - Ghana 2019).

\section{Impact of inland ports}

Some literatures have covered inland ports operations over the past two centuries but there are large variations and diversities regarding the focus of the study (Witte et al. 2019). Among the several existing literature on inland ports, very few focus on the impact of inland ports on the freight transport system. Asef-Vaziri (2019) pointed out that the development of inland ports in Southern California "increased transportation efficiency since it supported train transport (Kenney 2017), created a smoother flow on the highways, created a cleaner environment, increased the capacity of the ports, reduced the demands on port land and promoted inland economic and logistics integration." Monios (2011) had explained that inland ports do not merely serve as transport hubs but rather function as locations for distribution activities, hence enhancing supply chain activities. Inland ports unburden the capacity of the ports in the freight transport system by offering supporting capacity (Rožić et al. 2016) and also become a competitive advantage for a less developed port that cannot serve all its connections. Dry ports effectively satisfy the cargo consolidation needs in the freight transport system making transportation flow, even over longer distances to be smooth (Jaržemskis and Vasiliauskas 2007). Jeevan et al. (2019) examined the impact of inland ports on seaport competitiveness and concluded that Inland ports enhance seaport performance, increase service variations for seaports, improve seaport-hinterland proximity, increase seaport trade volume, and enhance seaport capacity. These literatures all support that inland ports have positive impacts and are beneficial to the freight transport system.

\section{Challenges of freight transport system}

The freight transport system faces some notable challenges that impede the efficiency and interrupts free transport flow. Meersman et al. (2016) argued that we are in the digital era and big data exist in abundance. This poses a challenge to the freight transport system because volume of transactions occurs and IT infrastructures are needed to gather the range of varied data, process, store, and issue them. The authors argued that several ports still note information on paper and this practice is not able to keep up with the trend of big data in this digital era. The vast availability of data poses a greater 
challenge to the Freight transport system in terms of handling, identifying the appropriate and relevant data, selecting the relevant and necessary data, best handling and use of relevant data. Another challenge that has been bothering the freight transport system for years is coordination challenges (Gumuskaya et al. 2020). Seaports connected to hinterlands such as the Takoradi and Tema ports in Ghana require multimodal transport. Coordinating transhipment activities and intermodal transport pose challenges to the freight transport system. Bouchery et al. (2015) explained that coordinating the intermodal transport systems requires efficient management of the parties in the chain and effective information exchange. The freight transport system encounters difficulty in designing an effective regulatory framework that will manage all the parties within the chain (Kijewska et al. 2019; Behdani et al. 2019). In a study on the challenges to increase sustainable urban freight transport, Kijewska et al. (2019) mentioned that freight transports encounter several challenges that can be categorized as economic and business challenges, social challenges, and environmental challenges. The economic and business challenges include issues such as poor intermodal transport, congestions, higher cost of maintaining freight infrastructures, barriers to freight mobility, and traffic accidents. Some social issues include poor access to transport facilities, the negative impact of transport on human health, inability to satisfy social needs, and lack of transport diversity. The environmental challenges include the impact on climate change, pollution of water, air and land, poor land use, incessant noise generation, and depletion of natural resources. These are some revealed challenges within the freight transport system across the globe that require the attention of both researchers and practitioners.

\section{Methodology}

An explorative case survey design was used for this study. This design was chosen to gather data on individuals' opinions and existing reports on the Boankra inland port project (Shuttleworth 2008).

The study sought to advance information from individuals involved in the freight transportation and logistics process at the Boankra inland port project. The target population for the study comprised all organizations operating at the seaport as freight forwarders, shipping agents, cargo owners, and various government agencies that work directly or indirectly with the Boankra project. A 35 member committee was established to oversee the construction of the Boankra Inland Port. The members of the committee are top managerial personnel within the West African Freight Transport system. From the target population, a sample of 32 respondents was chosen for the study, and 3 members were not available. Hence, an experienced survey was conducted with the 32 respondents who were in top managerial positions within the actor firms in the freight transport system. Since this project is in the implementation phase, very few respondents are privy to the necessary information needed for the study. Therefore, this study utilized purposive sampling to select the respondents that have power over information concerning the inland project and as such, was in a better position to provide accurate information. Francis et al. (2010) explained that in interview case studies, the sample size is often justified by interviewing participants until reaching "data saturation." For a study with limited information available, a case study with expert participants is recommended (Vasileiou et al. 2018). Since the study was conducted on an ongoing project, the members of the committee constitute the expert group and they were purposively sampled 
for the study. The questionnaires were filled with the respondents and explanations were inquired from the respondents where necessary.

Data collection was made to test the essence of inland ports in a developing African economy as stated by Kombo and Tromp (2006). The study adopted both primary and secondary data. The secondary data was collected from organizational policy documents, published books, journals, and other vital written documents on the Boankra inland port project while the primary data was gathered using questionnaires through and experience survey.

Closed-ended questionnaires were used because they had fixed responses and enabled the researchers to shape the responses so that the respondent will be restricted to provide information that is vital to the study. The items on the questionnaires were adapted from prior literature (Gallagher 2017; Harrison et al. 2004; Inkinen et al. 2019; Kijewska et al. 2019) and revised to fit the study context. The questionnaires were administered to the respondents personally and filled with them. Further information to the responses given by the respondents was noted and factored into the analysis.

To establish the content and construct validity of the instrument, the researchers sought opinions of two specialists who are professors in Maritime logistics and as such are experienced in the field of study. This required correction, modification, and alteration of the study instrument subsequently upgrading and enhancing its validity. The data gathered through questionnaires were checked, coded, and summarized for completeness and its comprehensiveness. The general analysis was done using Statistical Package of Social Science (SPSS) software version 21.0. The analyses were presented using frequency tables and percentages.

\section{Data analysis}

The study distributed questionnaires among 32 respondents across the port industry in Ghana which included the freight forwarders, shipping agents, Burkina /Mail chamber of commerce, Ghana importers association, cargo owners, port and harbours Authority, Haulage transport association, private terminal operators, Ghana Railway Development Authority, Ministry of Transport and Ministry of Trade and Industry. Out of the 32 questionnaires administered, only 30 were answered completely since the respondents had the liberty to skip questions they did not want to respond to. Thus, there was a response rate of $93.75 \%$. Two respondents representing $6.25 \%$ did not meet the standard for the study and therefore, their responses were rejected. The respondents are sufficient representation of the population since they are lead members in the Ghanaian freight transport System and have in-depth information. Therefore, the response rate of $93.75 \%$ authenticates Joppe's (2000) proclamation that a response rate greater than $50 \%$ is adequate for generalization. However small the sample size is, it covered all the representatives of the various actors within the port industries. Therefore, the study outcome can be generalized across Ghana and other developing countries within the Sub-Saharan African Region.

\section{Perceived potential impact of Boankra inland port project on the freight transport sector in Ghana}

The respondents ranked the level of congestion at the Ghanaian seaports based on their level of knowledge, understanding, and perception. Table 1 below represents the outcome of the responses: 
Table 1 There is high congestion at the sea ports

\begin{tabular}{lll}
\hline Response & Frequency & Percent \\
\hline Strongly disagree & 2 & 6.7 \\
Neither agree nor disagree & 2 & 6.7 \\
Agree & 19 & 63.3 \\
Strongly agree & 7 & 23.3 \\
Total & 30 & 100.0
\end{tabular}

Source: Field Data (2018)

To obtain the impact of the Boankra inland port project on the freight transport sector in Ghana, a question was posed to find out whether there is a high congestion level at the seaports. Seven of the respondents strongly agreed and 19 of the respondents agreed that the Tema and Takoradi Seaports face congestion problems. However, 2 people out of the 30 respondents neither agreed nor disagreed whiles 2 people also strongly disagreed with that fact. From the above information, it was observed that the majority of the respondents are of the view that there is high congestion at the seaports. Having established that the seaports in Ghana face congestion, the study's objective becomes much more relevant as the potential influence of the Boankra inland port on the decongestion of the seaports can be examined. Oyatoye et al. (2011) argued that traffic through the seaports increase as the economic development of the country develops. Fan et al. (2012) also revealed that congestion exists at most ports and it results in increased costs and diversion of traffic to other ports. Therefore, this study confirms that port congestion continues to persist in ports, at least, the Ghanaian seaports. Considering the argument made by Oyatoye et al. (2011), it can be explained that the increase in the volume of trade and the growth in international trade in Ghana is a reason for the persisting congestion at the Tema and Takoradi seaports.

From Table 2, all the respondents agreed to the fact that the port will increase the skills of the staff. From the respondents, before the kick-start of the Boankra inland port project, workshops, and training were given to the inland port implementing staff and this has given them more opportunity to learn and increase their skills. Eighteen of the respondent strongly agreed and 12 respondents agreed to this fact. No respondent disagreed with the statement. It implies that the Boankra inland port project will not only provide shipping infrastructure but will also strengthen the capacity of the human force within the freight transport industry in Ghana. A strengthened human force will also have the capacity to influence the competence of the workforce (Gong et al. 2009) which in turn will have a positive influence on the efficiency of the Ghanaian freight transport industry. This reveals that the Boankra inland port has the potential to impact the freight transport system in Ghana and Sub-Saharan Africa (Table 3).

Table 2 The Boankra inland port has increased skills of staff

\begin{tabular}{lll}
\hline Response & Frequency & Percent \\
\hline Agree & 12 & 40.0 \\
Strongly agree & 18 & 60.0 \\
Total & 30 & 100.0 \\
\hline
\end{tabular}

Source: Field Data (2018) 
Table $\mathbf{3}$ Use of advanced management information systems

\begin{tabular}{lll}
\hline Response & Frequency & Percent \\
\hline Neither disagree nor agree & 1 & 3.3 \\
Agree & 15 & 50.0 \\
Strongly agree & 14 & 46.7 \\
Total & 30 & 100.0 \\
\hline
\end{tabular}

Source: Field Data (2018)

For a freight transport system to operate effectively and efficiently, it must have a well-structured management information system to track the progress of the activities within it. Through the implementation of the Boankra inland port, there will be intensive use of a more advanced management information system than when the inland port was not proposed. This information was obtained from the 29 respondents who agreed to the fact that the port will have an impact on the freight sector through the use of a management information system. However, 1 person among the respondents neither agreed nor disagreed that an enhanced Information System at the Boankra Inland Port will influence the decongestion and efficiency of the Sea Ports. The freight forwarders and the Burkina Faso Chamber of Commerce revealed explained that here will be real-time information and accurate data which will facilitate clearance at the seaports. The freight transport sector is an industry where new digital applications are integrated into the daily operations and practices in a more slowly manner (Inkinen et al. 2019). Kia et al. (2000) defined that information technology is an important component of port operations for the rapid and accurate transfer and processing of the larger volume of information that is handled by the actors within the freight Transport System. Therefore, the incorporation of the management information system into the Inland Port project is a basic necessity for the functioning of the port.

Policies are said to be laid down rules that govern the activities within an entity. Table 4 shows that the formation of powerful policies is useful in port decongestion processes (Munford 1980). Per the responses derived from the respondents, 10 of the respondents strongly agreed, 16 agreed, 3 neither agreed nor disagreed whiles 1 person strongly disagreed. From the analysis above, it implies that the establishment of the Boankra inland port will result in the formation of powerful policies useful in the port decongestion process. These policies that are being developed as a result of the implementation of the Boankra inland port project, from the perspective of the respondents, will help solve the loopholes and the weaknesses in the already existing policies. The development of the policies will also help solve the staff - customer problems and the problems associated with decongestion (Table 5).

Table 4 Formation of powerful policies useful in decongestion process

\begin{tabular}{lll}
\hline Response & Frequency & Percent \\
\hline Strongly disagree & 1 & 3.3 \\
Neither agree nor disagree & 3 & 10.0 \\
Agree & 16 & 53.3 \\
Strongly agree & 10 & 33.3 \\
Total & 30 & 100.0 \\
\hline
\end{tabular}

Source: Field Data (2018) 
Table 5 Adaptation of new technologies in cargo handling process

\begin{tabular}{lll}
\hline Response & Frequency & Percent \\
\hline Strongly Disagree & 2 & 6.7 \\
Agree & 11 & 36.7 \\
Strongly Agree & 17 & 56.7 \\
Total & 30 & 100.0 \\
\hline
\end{tabular}

Source: Field Data (2018)

Adaptation of new technologies simply means employing different and improved ways of doing things. This new technology will help speed up the activities of the port users. Through the establishment of the Boankra inland port, new technologies will be adopted in the industry which will promote the activities of the sector. This information was agreed by most of the respondents when the statement was posed to them in an attempt to find out the impact of the port on freight services. From the respondents, obsolete technologies were more in the sector but through the implementation of the inland port project, new technologies are being introduced, which are helping speed up their work. However, two people among the respondents opposed strongly to the fact that the implementation of the Boankra Inland project involves the adaptation of new technologies in cargo handling (Table 6).

The study took a look at the impact of the establishment of the Boankra inland port on the quality of road infrastructure. It was revealed that there has already been some massive impact of the inland port project on the quality of road infrastructure. Respondents mentioned that through the development of the inland port project, there has been an improvement in the road transport infrastructure through the redesign and expansion of the current road network to accommodate more vehicles into the project site. A typical example that solidifies the responses of the respondents is the recent rehabilitation of the Accra - Kumasi highway because of the Boankra Inland Port. The potential high usage of heavy-duty trucks to carry freight from the inland port to different parts of the country and beyond has created the need to increase the quality of the roads within Ghana. This finding was revealed by 22 respondents who agreed that there is an increase in the quality of road infrastructure. Four of the respondents neither agreed nor disagreed whiles 4 persons strongly disagreed with the statement. From the above analysis, it implies that there is a potentially strong impact of the Boankra inland port on the effectiveness and efficiency of the general freight sector (Table 7).

In most government institutions, there is a high level of bureaucracy and the same can be said for the Ghanaian seaports. This creates unnecessary delays in the clearing processes. Customers mostly complained about the long government processes they go

Table 6 Increase quality of road infrastructure

\begin{tabular}{llc}
\hline Response & Frequency & Percent \\
\hline Strongly disagree & 4 & 13.3 \\
Neither agree or disagree & 4 & 13.3 \\
Agree & 15 & 50.0 \\
Strongly agree & 7 & 23.3 \\
Total & 30 & 100.0 \\
\hline
\end{tabular}

Source: Field Data (2018) 
Table 7 Reduced bureaucracy in clearing processes at the sea port

\begin{tabular}{lll}
\hline Response & Frequency & Percent \\
\hline Disagree & 1 & 3.3 \\
Strongly disagree & 3 & 10.0 \\
Neither disagree nor agree & 1 & 3.3 \\
Agree & 10 & 33.3 \\
Strongly agree & 15 & 50.0 \\
Total & 30 & 100.0 \\
\hline
\end{tabular}

Source: Field Data (2018)

through before discharging their goods which in turn affects their businesses negatively. However, $83.3 \%$ of the respondents emphasized the fact that unlike previously when customers became discouraged because of the processes they go through before discharging their goods, the establishment of the Boankra inland port will drastically reduce the bureaucracy in the clearing processes (Table 8).

Privatization used in this study refers to entrusting the operation and management of container handling to private firms. The inefficiency and ineffectiveness of the government to manage containers led to the clustering of containers around the port. It was revealed by the respondents that the control of the port by the government contributes to the reason why the containers were clustered at the ports because there was lesser control over the port activities. However, $76.7 \%$ of the respondents agreed from their responses that there is the need to privatize the process of container handling. The respondents indicated that this will help reduce the current problems associated with container handling at the Ghanaian Sea Ports. $10 \%$ of the respondents neither disagreed nor agreed. However, $13.4 \%$ of the respondents disagreed the inland port will result in the privatization of the container handling processes.

As shown in Table 9, it was agreed by all the participants that the establishment of the Boankra inland port will allow the management of the seaports to actively monitor the movement of trucks in and out of the port through the institution of proper transit monitoring information system at the port area. This system is proposed to monitor the loading of trucks and the movement of containers at the depots. As a result, the trucks will leave the inland port and the seaports without human interference. It was also mentioned that as a way of overcoming the problem of congestion, the seaport management to some extent, will be actively involved in monitoring freight transit from the inland port to the seaports through a freight monitoring system.

Table 8 Privatization of container handling processes

\begin{tabular}{llc}
\hline Response & Frequency & Percent \\
\hline Disagree & 2 & 6.7 \\
Strongly disagree & 2 & 6.7 \\
Neither disagree nor agree & 3 & 10.0 \\
Agree & 15 & 50.0 \\
Strongly agree & 8 & 26.7 \\
Total & 30 & 100.0 \\
\hline
\end{tabular}

Source: Field Data (2018) 
Table 9 Use of freight monitoring system

\begin{tabular}{lll}
\hline Response & Frequency & Percent \\
\hline Agree & 12 & 40.0 \\
Strongly agree & 18 & 60.0 \\
Total & 30 & 100.0 \\
\hline
\end{tabular}

Source: Field Data (2018)

Table 10 shows the outcome of the impact of the inland port on ship arrival and departure time. From the majority of the respondents, there will be the use of appointment systems for trains, trucks, and ships' arrival and departure. This will help the authorities to pre-inform owners of the freight on board to be available within the said time of arrival or departure for clearing procedures to avoid congestion at the port. This will make cargo receiving agents at the seaports and inland ports to handle cargoes on time and clear them from the port within the shortest possible time. Notwithstanding the high level of agreement from the respondents, 2 of the respondents disagreed with the statement that there will be the use of appointment systems for freight arrival and Departure whiles 1 respondent neither agreed nor disagreed (Table 11).

From the analysis, it was revealed that the Boankra inland port will also increase the efficiency and speed of the cranes which will, in turn, improve the freight services at the inland port. This was obtained when all the 30 respondents agreed to the statement that the Boankra inland port will increase the efficiency and speed of cranes at the port.

From Table 12, 29 respondents agreed to the statement that there will be greater use of space-efficient packing/handling equipment. It was revealed that the Boankra inland port will have a total land area of about 400 acres around the port. This will provide enough space for efficient parking and handling of equipment. This will also reduce the congestion rate that occurs at the seaports since a substantial amount of cargo received by the seaports will be transferred to the inland port which will also in effect be cleared timely.

The Boankra inland port project has gained positive support from the key actors in the freight transport system that it will impact positively on the seaports, the inland port itself, and the freight industry at large. From the results discussed above, the Boankra inland port will reduce the bureaucratic processes at the seaports, increase the quality of road infrastructure, reduce the congestion rate and the pressure on the other ports and will also enhance the movement of freights to neighboring landlocked countries.

Table 10 Use of appointment systems for ship arrival and departure

\begin{tabular}{lll}
\hline Response & Frequency & Percent \\
\hline Disagree & 1 & 3.3 \\
Strongly disagree & 1 & 3.3 \\
Neither disagree nor agree & 1 & 3.3 \\
Agree & 12 & 40.0 \\
Strongly agree & 15 & 50.0 \\
Total & 30 & 100.0 \\
\hline
\end{tabular}

Source: Field Data (2018) 
Table 11 Increased efficiency and speed of the crane

\begin{tabular}{lll}
\hline Response & Frequency & Percent \\
\hline Agree & 16 & 53.3 \\
Strongly agree & 14 & 46.7 \\
Total & 30 & 100.0 \\
\hline
\end{tabular}

Source: Field Data (2018)

\section{Challenges in the Ghanaian freight transport system}

This section of the analysis presents the challenges in the freight transport industry revealed by the respondents and how these challenges affect the Boankra inland port project in Ghana.

Descriptive statistics were used to statistically measure the outcome of these items used to measure the challenges affecting the Freight Transport system and the Boankra Inland Port, using mean and percentages. The mean scores were used to rank the various challenges in order of magnitude, ranging from the most pressing challenge to the least pressing challenge. The item with the highest mean is the major factor that affects the freight forwarding transport system in Boankra and the variable with the lowest mean score is considered as the less significant challenge in the freight forward system.

"Poor understanding of logistics as a distinct management function" was ranked as the most pressing challenge among all the variables with a mean score of 4.6. Twelve respondents representing 40\% agreed whiles 18 respondents representing (60\%) strongly agreed to the statement. This could be attributed to the fact that the Boankra inland port in its nature is a virgin port system and therefore lacks the necessary organizational structures. Nevertheless, the challenge persists in the current seaports in Ghana. It indicates that less knowledge or importance is attached to the logistics function. Failure to understand logistics as a distinct strategic function within the Ghanaian Freight system is a big challenge to the growth of the system.

Also, the result shows that "inefficiencies and distortions in the trading system" are ranked the second most challenging factor hindering the seaports. The item had a mean score of 4.43 out of 5 and this item was agreed by $93.4 \%$ of the respondents whiles 2 respondents representing $6.6 \%$ disagreed. This was followed by the "unnecessary bureaucratic procedures at the ports" with a mean score of 4.40: 28 respondents representing 93.4\% strongly agreed whiles 2 respondents representing $6.6 \%$ disagreed with the statement. In most government institutions there is a high level of bureaucracy, which the ports are of no exception. This creates unnecessary delays in the clearing processes. Customers (freight forwarders) complained about the long clearing processes they go through before discharging their goods which affect their businesses and the businesses of their clients negatively.

"Weak regulatory framework," "Poor quality control" and "cumbersome customs procedures and poor articulation of total quality management" were ranked as the pressing

Table 12 Greater use of space-efficient packaging/handing equipment

\begin{tabular}{lll}
\hline Response & Frequency & Percent \\
\hline Strongly disagree & 1 & 3.3 \\
Agree & 16 & 53.3 \\
Strongly agree & 13 & 43.3 \\
Total & 30 & 100.0 \\
\hline
\end{tabular}

Source: Field Data (2018) 
challenges following the above-mentioned challenges. The respondents indicated that the "weak regulatory framework" is as a result of the continual change in government. This has resulted in inefficiency and a lack of expansion in the freight transport industry.

"Inadequately skilled staff" and "high level of political instability" were ranked eighth with mean scores of 4.10 each: $93 \%$ agreed that skilled staffs still in the industry are not enough to cater to all the needs of customers. The respondents indicated that it is so because of the government's inability to employ more staff.

"Lack of capital" is another challenge facing ports in Ghana. A discussion with one respondent revealed that the port needs a huge amount of money to procure new and ultra-modern highspeed machinery like forklifts and cranes to carry out the operations of the inland ports when it starts operation. The respondent explained that these items are too expensive to procure by the port management since they do not have enough funds to procure. The respondents called on the government to intervene in the procurement of these items for the ports. $86.7 \%$ of the respondents representing 28 respondents agreed that lack of capital is a challenge in the Ghanaian ports industry whiles 2 respondents representing 13.3\% disagreed with the statement. The respondents revealed that the procurement of these machinery and auto operations of the port activities will highly decrease theft and cargo breakage situation at the ports, increase the speed of shipping and offloading cargos at the port, simplifies the clearing procedures by making it free from corruption and eventually increase the quality of service delivery within the freight transport industry.

In conclusion, the Ghanaian ports have been hindered by various factors including the poor understanding of logistics as a distinct management function, inefficiencies and distortions in the trading system, and unnecessary bureaucratic procedures. All these challenges need to be addressed to ensure better implementation and functioning of the Boankra inland port. The challenges revealed in the study are presented in Table 13. These challenges discovered in this study holds for the port system in most developing economies, especially those in West Africa.

Table 13 Challenges of the Ghanaian freight transport system

\begin{tabular}{|c|c|c|c|c|c|c|c|}
\hline Items & $\mathrm{N}$ & Min & Max & Mean & $\begin{array}{l}\text { S. } \\
\text { Agree } \\
\%\end{array}$ & $\begin{array}{l}\text { Disagree } \\
\%\end{array}$ & Ranking \\
\hline Inefficiencies and distortions in the trading system & 30 & 1 & 5 & 4.43 & $93 \%$ & $6.6 \%$ & 2nd \\
\hline Weak regulatory framework & 30 & 1 & 5 & 4.33 & $93.6 \%$ & $6.6 \%$ & 4th \\
\hline Lack of capital / funds for infrastructure & 30 & 1 & 5 & 4.23 & $86.7 \%$ & $13.3 \%$ & 7th \\
\hline $\begin{array}{l}\text { Use of Low management Information system/ } \\
\text { Technology }\end{array}$ & 30 & 1 & 5 & 3.33 & $70 \%$ & $30 \%$ & 12th \\
\hline Inadequacy of staffs & 30 & 1 & 5 & 4.10 & $93.4 \%$ & $6.6 \%$ & 8th \\
\hline Lack of continuity of government policies & 30 & 1 & 5 & 4.27 & $93.4 \%$ & $6.6 \%$ & 6th \\
\hline $\begin{array}{l}\text { Poor quality control and cumbersome customs } \\
\text { procedures }\end{array}$ & 30 & 1 & 5 & 4.33 & $96.3 \%$ & $3.3 \%$ & 4th \\
\hline Poor application of just in time principle & 30 & 1 & 5 & 3.93 & $83.7 \%$ & $16.7 \%$ & 11th \\
\hline Poor articulation of total quality management & 30 & 1 & 5 & 4.33 & $93.4 \%$ & $6.6 \%$ & 4th \\
\hline $\begin{array}{l}\text { Poor understanding of logistics as a distinct management } \\
\text { function }\end{array}$ & 30 & 1 & 5 & 4.60 & $100 \%$ & 0 & $1 s t$ \\
\hline High level of Political instability & 30 & 1 & 5 & 4.10 & $83.7 \%$ & $16.7 \%$ & 8th \\
\hline Incompetence among stakeholders & 30 & 2 & 5 & 4.00 & $83.7 \%$ & $16.7 \%$ & 10th \\
\hline Unnecessary bureaucratic procedures & 30 & 2 & 5 & 4.40 & $93.4 \%$ & $6.6 \%$ & $3 \mathrm{rd}$ \\
\hline
\end{tabular}

Source: Field Data (2018) 


\section{Summary, conclusion and recommendations \\ Summary}

Based on the analysis, it is found that the Boankra inland port project can reduce the inefficiencies and congestion problems associated with the Ports of Tema and Takoradi. The problems associated with congestion at the Ports may minimize at the two main seaports and will not occur at the Boankra inland port due to the vast land size (400 acres) available to the Boankra inland port (Pellegram 2001) and the ship appointment system for freight arrival and departure. It was also found that communities close to the inland port could now boast of quality road infrastructure and other social amenities that could improve the standard of living. Factors such as the increase in skills and experience of personnel, the use of management information systems, formulation of programmes and policies in decongesting the two main Ghanaian seaports, enhanced road network, adaptation of new technologies in the cargo handling process, and reduced bureaucracy in clearing processes at the ports are arbitrating factors through which the establishment of the Boankra inland port may have an impact on the seaports and the Freight transport industry at large. It, therefore, supports that port regionalization is not rather an imposition on the seaports, but rather a complement to the efficiency of seaports. Thus, some activities could be transferred to the Boankra inland port for customers to access their freights instead of traveling to Tema or Takoradi for freight clearance.

From the analysis, it was found that there are some challenges that the Maritime Ports are tagged with which do not promote the development of the sector and the economy at large (Gallagher 2017). The poor implementation of logistics as a distinct management function was seen as the major challenge which needs an immediate solution.

Also, it was found that there are inefficiencies and distortions in the trading system due to excessive political interference in the seaport operations; it makes it difficult for Port managers to design policies and programs that make the Ghanaian ports more competitive in the sub-region. Besides, there is poor coordination between managers of the port and some key stakeholders such as the importers' Associations and Haulage companies. This mostly affects the decision-making process on some issues.

It was also seen that the bureaucratic process at the ports creates frustration for importers and some stakeholders. Another issue that cannot be overemphasized is the inadequate fund available for the implementation of projects within the sector. The majority of programs intended to improve efficiency at the Ghanaian ports are capital intensive. The Ports find it difficult to raise adequate finance to support such programmes.

From the analysis, it was found that human capacity development is considered as one of the core duties that management of the Boankra inland port should consider to promote efficiency in the freight transport industry.

The challenges which may impede the improvement of freight transport in Ghana are inefficiencies and distortions in the trading system, unnecessary bureaucratic clearing processes, weak regulatory framework, Poor quality control, inadequate staff, political interference, and lack of capital. These challenges in the industry may turn to 
defect the development of the ports despite the implementation of the Boankra inland port and for that matter, much attention should be paid to.

From the respondents, strategies that can be adopted to overcome the said challenges and to increase productivity is to strengthen the institutional capacity; provide relevant in-service training to officials, invest in infrastructure, development of railway and road infrastructure to reduce road traffic crashes. Therefore, for the Boankra Inland port to be sustainable, and meet project expectations, there is the need to review the strategic plan continuously, seek sustainable financing even after the construction of the Port. The government should provide the relevant legal and regulatory framework to protect the administrators of the Port from political and legal threats.

The participants suggested some strategies that could be employed to promote the efficiency of the Boankra Inland Port project and the Ghanaian freight transport system at large. As summarized in Table 14 in the Appendix, the respondents indicated that the officials and stakeholders must be trained; the various institutions in the transport chain must be empowered; corruption among port officials must be managed; there must be minimal political interference in the port operations; there must be more investment into the freight transport system, and there must be trade regulations to govern the freight transport system.

Rimmer and Comtois (2009) had argued that regionalization is nothing but decentralization of the freight transport system. However, Rodrigue and Noteboom (2010) objected and counter-argued that regionalization goes beyond decentralization to include the usage of more expansive strategies such as the linkage of the ports to inland freight distribution centers. This study has investigated these two arguments using the Boankra inland port and the study supports the argument made by Rodrigue and Noteboom (2010) by revealing that the Boankra inland port is not just a decentralization of the seaports, but rather an essential component of the freight transport system that could impact on other transport modes, the seaports, and the inland depots in landlocked neighboring countries.

\section{Conclusion}

The primary reason for this study is to contribute to the improvement of freight transport in Ghana. The findings suggest that Boankra inland port serves as a more efficient solution to congestion problems at the Ghanaian Seaports and a means to reduce the transportation cost for cargo shipped to hinterland destinations. Therefore, the Boankra inland Port is a rational and cost-efficient location for freight transiting.

Again, environmental problems and traffic congestion at the seaport will be reduced, as volumes of containers from the seaports will be moved to the inland port for clearance. Hence, the study can predict that the Boankra inland port will improve a greater level of international trade with landlocked countries such as Burkina Faso, Mali, and Niger. It will also promote industrial growth in the hinterland and trigger economic boom within Ghana and the surrounding regions. The creation of the inland port will create more jobs in the industry and with the introduction of enhanced information and communication management systems; there will be a need to upscale the skills and knowledge of the key staff of the Port. The study also revealed that Boankra has a critical location to serve as a transit along the Tema- Kumasi- Paga corridor. It is equidistant from key freight markets in the Agricultural and mining communities and closer to the Northern landlocked countries than the Tema and Takoradi ports. There is also enough land 
available at the inland port area to cater for an increased container traffic and future extension of the port.

\section{Study limitations}

The study has some limitations and assumptions underlying the findings made. First, the study model was developed based on the project plan drawn for the Boankra Inland Port. It was assumed in the study that the plan will remain the same and will be successfully executed. However, there is a possibility that the project plan may be changed and that may affect its function in the freight transport system.

Secondly, the study relied on a fewer sample size that the researcher perceived to be experienced subjects who are capable of providing accurate responses. The sample is assumed to be a representative of all the actors in the Sub-Saharan African Freight Transport system. There might have been different responses if a wider survey on a larger sample size had been conducted.

Finally, this study is a case study based on the Boankra Inland port and the Ghanaian freight transport system. The findings may not apply to every inland port project.

\section{Recommendations and implications Implication for practitioners}

Recommendations have been made about procedures that could be taken to improve freight transport in Ghana based on findings made.

The Government of Ghana may support the building and provision of some infrastructure that will meet current developments and technological changes in the freight shipping industry. The Boankra inland port can have some features such as warehouses, area for container stacking, tracking, parking, and a devanning area.

Offloading cargo to the hinterland will help decrease congestion in the seaport area (Ferrari et al. 2011; Frémont and Franc 2010); however, a lot of the responsibilities need to be placed on the organizations responsible for clearance processes and carriage of cargo to reduce the amount of time cargo spend within the Ports.

The Government may create an environment that enables the private sector to invest in inland ports. There should be the regulatory and statutory framework to ensure that all primary and third-party freight and logistics organizations are properly regulated in their activities at the ports. There should be a review of the bureaucratic clearing processes at the Ghanaian ports.

Management of the Ports should conduct a human resource audit on all staff of the ports in a bid to improve their capacity.

Finally, the Boankra inland port should provide more value-added logistics services to sustain revenue generation for its continual operation.

\section{The implication for academics and scientific knowledge}

This study brings out explorative knowledge on the implementation of Inland ports in Africa and its role in the Freight transport system. This closes the gap identified by Witte et al. (2019) that only one study has been conducted on inland ports in Africa which were conducted in East Africa. This study is conducted in West Africa to add up to the scientific knowledge of Inland ports in Africa and to argue out that port regionalization is a favorable theoretical concept that must be supported with the development of inland ports. 


\section{Appendix}

Table 14 Efficiency strategies that can be employed in the Ghanaian freight system

\begin{tabular}{|c|c|c|c|c|c|c|c|}
\hline Items & $\mathrm{N}$ & Min & Max & Mean & $\begin{array}{l}\text { S. Agree } \\
\%\end{array}$ & $\begin{array}{l}\text { Disagree } \\
\%\end{array}$ & Variance \\
\hline $\begin{array}{l}\text { Providing relevant training to officials and } \\
\text { stakeholders }\end{array}$ & 30 & 1 & 5 & 4.37 & $96.7 \%$ & $3.3 \%$ & .309 \\
\hline $\begin{array}{l}\text { Providing training to Freight forwarders and port } \\
\text { officials }\end{array}$ & 30 & 1 & 5 & 4.23 & $87.7 \%$ & $13.3 \%$ & .875 \\
\hline Institutional empowerment & 30 & 1 & 5 & 4.37 & $93.4 \%$ & $6.6 \%$ & .516 \\
\hline $\begin{array}{l}\text { Managing perception of corruption among port } \\
\text { officials }\end{array}$ & 30 & 1 & 5 & 4.20 & $87.7 \%$ & $13.3 \%$ & 1.200 \\
\hline Instituting trade regulations and requirements & 30 & 1 & 5 & 3.87 & $83.7 \%$ & $16.3 \%$ & 1.223 \\
\hline Minimising political interferences in port operations & 30 & 1 & 5 & 4.30 & $93.4 \%$ & $6.6 \%$ & 1.045 \\
\hline Massive investment in infrastructure & 30 & 1 & 5 & 4.07 & $87.3 \%$ & $13.3 \%$ & 1.168 \\
\hline
\end{tabular}

Source: Field Survey (2018)

A future study is proposed to experiment to measure the actual influence of the Boankra Inland port (after its completion) on the efficiency of the Freight Transport System in Ghana to further advance knowledge in this field.

\section{Abbreviations}

GPHA: Ghana Ports and Harbours Authority; AICD: Africa infrastructure diagnostic report; GoG: The Government of Ghana; GSA: Ghana Shippers Authority; TRCB: Terminal Routier à Conteneur de Boborinter; SETO: Société d'Exploitation du Terminal de Ouagadougou; ICD: Inland Container Depot

\section{Acknowledgements}

The Researchers acknowledge the port officials and the project leads for the Boankra Inland port who provided the data for this study.

\section{Authors' contributions}

Richmond Kwesi Ansah: literature search and review, conducted field interview and distributed questionnaire, data analysis, wrote final report, and correction of revision. Kwabena Obiri-Yeboah: Writing of problem statement, review of the report, funding of the project, and review of corrected revision. Grace Ayoka Akipelu: profreading and editing of the report, questionnaire distribution, and revision. The author(s) read and approved the final manuscript.

\section{Funding}

The study was funded from the authors' own resources.

\section{Availability of data and materials}

The data gathered for this study is available and will be produced upon request.

\section{Competing interests}

There is no competing Interest.

\section{Author details}

${ }^{1}$ Hong Kong Baptist University, Kowloon Tong, Hong Kong. ${ }^{2}$ Kwame Nkrumah University of Science and Technology, Kumasi, Ghana.

Received: 22 December 2019 Accepted: 11 May 2020

Published online: 25 May 2020

\section{References}

Asef-Vaziri A (2019) Impact of an inland port on the Inland Empire's freight transportation network (no. 19-00580) Bank of Ghana (2015). Results of Gog Tender 1417. Retrieved January 23, 2015, from Bank of Ghana- https://www.bog.gov. gh/markets/weekly-publication-of-gog-treasury-bill-auction-results/3639-results-of-gog-tender-1597

Bartlett CA, Ghoshal S (2002) Managing across borders: the transnational solution. Harvard Business Press, Brighton

Behdani B, Fan Y, Bloemhof JM (2019) Cool chain and temperature-controlled transport: an overview of concepts, challenges, and technologies. In: Sustainable food supply chains. Academic Press, Amsterdam, p 167-183

Beresford, A. K. C. and Dubey, R.C. (1990). Handbook on the management and operation of dry ports. UNCTAD, Geneva Bird J (1980) In: Bird J (ed) Seaports and seaport terminals. Hutchinson University Library, London, p 117

Bollore Ports (2019). Inland container depots. Retrieved from https://www.bollore-ports.com/en/our-port-expertises/inlandcontainer-depots.html on 14 Sept 2019. 
Bouchery Y, Fazi S, Fransoo J (2015) Hinterland transportation in container supply chains. In: Handbook of ocean container transport logistics, International series in operations research \& management science, p 220 BusinessGhana. (2018). 7 Investors Jostle for Boankra inland port project. Retrieved from https://www. businessghana.com/site/news/general/170802/7-Investors-jostle-for-Boankra-Inland-Port-project on 9 Sept 2019

ESCAP (2010), Institutional and regulatory issues for the development and operation of dry ports.,

Fan L, Wilson WW, Dahl B (2012) Congestion, port expansion and spatial competition for US container imports. Transp Res E Logist Transp Rev 48(6):1121-1136

Ferrari C, Parola F, Gattorna E (2011) Measuring the quality of port hinterland accessibility: the Ligurian case. Transp Policy 18(2):382-391

Francis JJ, Johnston M, Robertson C, Glidewell L, Entwistle V, Eccles MP, Grimshaw JM (2010) What is an adequate sample size? Operationalising data saturation for theory-based interview studies. Psychol Health 25(10):1229-1245

Frémont A, Franc P (2010) Hinterland transportation in Europe: combined transport versus road transport. J Transp Geogr 18(4):548-556

Gallagher J (2017) Three of the biggest challenges facing the freight and logistics industry

Ghana Ports and Harbours Authority (2014). Takoradi port. Retrieved December 18, 2019, from Ghana Ports: Http://Ghanaports.Gov.Gh/Tm/Default

Ghana Shippers Authority (2019). Boankra inland port. Retrieved from https://shippers.org.gh/index.php/projects/boankra/ on 12 Sept 2019

Global Infrastructure Facility (2018). Ghana Boankra inland port and eastern rail line. Retrieved from https://www. globalinfrafacility.org/sites/gif/files/GIFBriefs_PDA_April2018_Ghana\%20Boankra.pdf on 12 Sept 2019

Gong Y, Law KS, Chang S, Xin KR (2009) Human resources management and firm performance: the differential role of managerial affective and continuance commitment. J Appl Psychol 94(1):263

Gumuskaya V, van Jaarsveld W, Dijkman R, Grefen P, Veenstra A (2020) A framework for modelling and analysing coordination challenges in hinterland transport systems. Marit Econ Logist 22(1):124-145

Harrison R, McCray JP, Prozzi J (2004) Inland port transportation evaluation guide (CTR 4083-P4). Center for Transportation Research (CTR). University of Texas, Austin

Inkinen T, Helminen R, Saarikoski J (2019) Port digitalization with open data: challenges, opportunities, and integrations. J Open Innov Technol Market Complex 5(2):30

Jaržemskis A, Vasiliauskas AV (2007) Research on dry port concept as intermodal node. Transport 22(3):207-213

Jeevan J, Chen SL, Cahoon S (2019) The impact of dry port operations on container seaports competitiveness. Marit Policy Manag 46(1):4-23

Joppe G (2000) Testing reliability and validity of research instruments. J Am Acad Bus Cambridge 4(1/2):49-54

Kenney EEB (2017) "Super-port to the world?": an impact assessment of the Midwest Inland Port (Doctoral dissertation, Massachusetts Institute of Technology)

Kia M, Shayan E, and Ghotb F (2000) "The importance of information technology in port terminal operations". Int J Phys Distrib Logist Manag 30(No. 3/4):331-344. https://doi.org/10.1108/09600030010326118

Kijewska K, Iwan S, Korczak J (2019) Challenges to increase the sustainable urban freight transport in South Baltic Region-LCL project. Transp Res Proc 39:170-179

Kombo DK, Tromp DL (2006) Proposal and thesis writing: an introduction, vol 5. Paulines Publications Africa, Nairobi, pp 814-830

Kondo FA (2014) In land container depots and container freight services decongestion strategies: the case study of Tanzania ports authority. Doctoral dissertation, The Open University of Tanzania, Dar es Salaam

Logistics Capacity Assessment (2019a). Ghana port of Takoradi. Retrived from https://dlca.logcluster.org/display/public/ DLCA/2.1.1+Ghana+Port+of+Takoradi on 20 Mar 2020

Logistics Capacity Assessment (2019b). Ghana port of Tema. Retrived from https://dlca.logcluster.org/display/public/ DLCA/2.1.1+Ghana+Port+of+Takoradi on 20 Mar 2020

Meersman H, Ehrler VC, Bruckmann D, Chen M, Francke J, Hill P, Vierth I (2016) Challenges and future research needs towards international freight transport modelling. Case Stud Transp Policy 4(1):3-8

Ministry of Finance (2019). The Boankra inland port project. Retrieved from http://www.ppp.mofep.gov.gh/project/54/ boankra-inland-port-project on 14 Sept 2019

Monios J (2011) The role of inland terminal development in the hinterland access strategies of Spanish ports. Res Transp Econ 33:59-66

Monios J, Wilmsmeier G (2012) Giving a direction to port regionalisation. Transp Res A Policy Pract 46(10):1551-1561

Munford C (1980) Buenos Aires - congestion and the dry port solution. Cargo Syst Int J ICHCA 7(10):26-27

Notteboom TE, Rodrigue JP (2005) Port regionalization: towards a new phase in port development. Marit Policy Manag 32(3):297-313

Obeng S (2010) Decongestion strategies implemented by Ghana port authority. Kwame Nkrumah University, Ghana

Oyatoye EO, Adebiyi SO, Okoyee JC, Amole BB (2011) Application of queueing theory to port congestion problem in Nigeria

Patalinghug EE, Llanto GM, Fillone AM, Tiglao NC, Salazar CR, Madriaga CA, Arbo MDG (2015) A system-wide study of the logistics industry in the greater capital region (no. 2015-24). PIDS discussion paper series

Pellegram A (2001) Strategic land use planning for freight: the experience of the Port of London Authority, 1994-1999. Transp Policy 8(1):11-18

Rimmer PJ, Comtois C (2009) China's container-related dynamics, 1990-2005. GeoJournal 74(1):35-50

Rodrique, J. P., \& Notteboom, T. (2010). Foreland-based regionalization: Integrating intermediate hubs with port hinterlands. Research in Transportation Economics 27(1):19-29.

Rodrigue JP, De Brie J, Fremont A (2010) Functions and actors of inland ports: European and north American dynamics. J Transp Geogr 18(4):519-529

Roso V (2008) Factors influencing the implementation of a dry port. Int J Phys Distrib Logist Manag 38(10):782-798

Rožić T, Rogić K, Bajor I (2016) Research trends of inland terminals: a literature review. Promet-Traffic Transp 28(5):539-548

Shuttleworth, M, 2008. Case study research design. Podcast retrieved from http:/umw.experiment-resources.com/case-study research-design.htm

Slack B (1999) Satellite terminals: a local solution to hub congestion? J Transp Geogr 7:241-246 
Van den Berg R, De Langen P (2015) Towards an 'inland terminal centered' value proposition. Marit Policy Manag 42(5):499-515 Vasileiou K, Barnett J, Thorpe S, Young T (2018) Characterising and justifying sample size sufficiency in interview-based studies: systematic analysis of qualitative health research over a 15-year period. BMC Med Res Methodol 18(1):148

Veenstra AW, Zuidwijs R, van Asperen E (2012) The extended gate concept for container terminals: expanding the notion of dry ports. Marit Econ Logist 14(1):14-32

Wilmsmeier M, Monios J, Lambert B (2011) The directional development of intermodal freight corridors to inland terminals. J Transp Geogr 19:1379-1386

Witte P, Wiegmans B, Ng AK (2019) A critical review of the evolution and development of inland port research. J Transp Geogr 74:53-61

\section{Publisher's Note}

Springer Nature remains neutral with regard to jurisdictional claims in published maps and institutional affiliations.

Submit your manuscript to a SpringerOpen ${ }^{\odot}$ journal and benefit from:

- Convenient online submission

- Rigorous peer review

- Open access: articles freely available online

- High visibility within the field

- Retaining the copyright to your article 